\title{
The Functions of Saliva
}

\author{
Mitchell D. Kaplan, DDS and Bruce J. Baum, DMD, PhD \\ Clinical Investigations and Patient Care Branch, National Institute of Dental Research, National Institutes of Health, Bethesda, \\ Maryland, USA
}

\begin{abstract}
Oral health is determined to a considerable extent by our abilty to produce saliva. Not only must adequate amounts be produced, but a large number of specific proteins also must be secreted for the mouth to function properly. This brief review is directed at describing (1) how saliva is secreted, (2) the consequences of decreased salivary function, (3) the components necessary for oral homeostasis, and (4) the common causes of salivary hypofunction.
\end{abstract}

Key words: Salivary secretion - Oral function - Alimentary process - Deglutition - Deglutition disorders.

\section{Principles of Salivary Secretion}

Salivary glands are composed of two general portions, the secretory endpiece, or acinar portion, and the ductal elements. Essentially, there are two stages in salivary fluid production. The first stage takes place in the acinar cells. Saliva is formed in response to neurotransmitter stimulation; there is no spontaneous salivary secretion. Neurotransmitters activate appropriate acinar cell receptors, leading to second-messenger generation within the cell. The two principal second messengers are cyclic AMP (cAMP) and inositol trisphosphate ( $\left.\mathrm{IP}_{3}\right)$. cAMP is coupled to protein exocytosis, and $\mathrm{IP}_{3}$ formation leads to cellular $\mathrm{Ca}^{2+}$ mobilization and the subsequent activation of several ion transport pathways which result in fluid secretion. This first stage of saliva formation yields an isotonic primary secretion. Acinar cells are entirely responsible for fluid secretion, transporting fluid and electrolytes from the serum to the forming saliva. In addition,

Address offprint requests to: B.J. Baum, CIPCB/NIDR/NIH, Building 10, Room 1N-113, Bethesda, MD 20892, USA acinar cells produce and secrete $85-90 \%$ of salivary proteins [1]. The second stage of salivation is fluid modification within the ductal region. In this segment of the gland there is considerable electrolyte reabsorption, rendering the saliva hypotonic, as well as the secretion of additional exocrine proteins. The final saliva that enters the mouth, on average, contains $\sim 25 \mathrm{mEq} / \mathrm{L}$ of $\mathrm{NaCl}$ and $\sim 2-5$ $\mathrm{mg} / \mathrm{ml}$ protein [2]. Serum proteins can be found in trace levels in secretions from healthy glands, but these levels can be greatly increased with disease, particularly in inflammatory conditions [3].

\section{Functions of Saliva and the Consequences of Salivary Dysfunction}

Saliva has several specific, essential functions (Table 1). These include protection of the oral mucosa and teeth, antibacterial action, facilitation of alimentation, physical cleansing, and buffering. Although one can certainly live without saliva, not having adequate salivary function can make life unpleasant. The significance of this body fluid can be most easily appreciated by evaluating individuals who have reduced salivary flow (see below). They have a wide range of complaints, including a feeling of dryness, alterations in taste (usually reflecting soreness or pain), and difficulty with mastication and swallowing. In addition to such subjective problems, certain clinical signs are associated with gland hypofunction. Most common is the presence of increased levels of decay (dental caries), often on tooth surfaces that are normally spared from this condition. Mucosal candidiasis is also common. Finally, many patients can present with a severe mucositis.

From this collection of signs and symptom's, saliva's tissue protective functions are evident. As noted in Table 1, these properties are generally mediated by specific proteins. It should be emphasized that all of the individual roles of saliva require adequate fluid output, 
Table 1. Functional properties of saliva

\begin{tabular}{|c|c|}
\hline Function & $\begin{array}{l}\text { Salivary component(s) } \\
\text { mediating function }\end{array}$ \\
\hline Mucosal protection & $\begin{array}{l}\text { Mucins, basic proline-rich } \\
\text { glycoprotein, epidermal growth } \\
\text { factor }\end{array}$ \\
\hline pH maintenance & Bicarbonate, histatins \\
\hline Microbial control & $\begin{array}{l}\text { Histatins, sIgA, lysozyme, } \\
\text { lactoferrin, salivary peroxidase, } \\
\text { fibronectin }\end{array}$ \\
\hline Remineralization of teeth & Statherin, proline-rich proteins \\
\hline $\begin{array}{l}\text { Alimentation, bolus } \\
\text { formation, translocation }\end{array}$ & Mucin, $\mathrm{H}_{2} \mathrm{O}$ \\
\hline Digestion & $\begin{array}{l}\text { Various hydrolytic enzymes: lingual } \\
\text { lipase, DNase, RNase, amylase }\end{array}$ \\
\hline $\begin{array}{l}\text { Taste mediation (as a solvent } \\
\text { and delivery system) }\end{array}$ & $\mathrm{H}_{2} \mathrm{O}$ \\
\hline
\end{tabular}

that is, the proteins require water for delivery to their site of action, and all functions occur in an aqueous environment. Thus, fluid secretion is the parameter commonly monitored in evaluating patients with suspected gland dysfunction [4], not specific salivary compositional changes. However, there are difficulties with relying on population standards for evaluating fluid production. Indeed, healthy persons show a 50 to 100 -fold range in basal secretions, while stimulated secretions vary by a factor of 10-20 [5]. Thus, adequate flow of saliva appears to be an individual characteristic. It has been suggested that if an individual's "normal" amount is reduced by $\sim 50 \%$ (whatever the starting value), symptoms will develop [6].

\section{Functions of Saliva and the Components Necessary for Oral Homeostasis}

\section{Dentition Protection}

Bacteria in the mouth, present in dental plaque adherent to teeth, may create a harsh, acidic environment that threatens the integrity of tooth structure. Calcium and phosphate are in a constant state of flux on tooth surfaces. Salivary proteins, such as proline-rich proteins (PRPs) and statherin, help maintain saliva supersaturated with these ions [7,8]. Saliva, thus, acts as a reservoir for rebuilding demineralized tooth structure that is lost as a consequence of low $\mathrm{pH}$. Additional tooth protection is derived from the lubricative properties of salivary molecules that form a film on the tooth surface known as the "acquired enamel pellicle." This is composed primarily of mucin-glycoproteins and lipids in addition to the PRPs and statherin [9]. This coating provides further protection from frictional wear as well as some protection from mineral loss secondary to the caries process [10].

\section{Mucosal Protection}

Recently, it has been suggested that certain salivary proteins bind specifically, and covalently, to oral mucosal cells [11]. This binding is catalyzed by transglutaminase, an enzyme located on the mucosal cell plasma membrane. Using radiolabeled saliva as a substrate, Bradway et al. [12] showed that this cross-linking process was selective and that the PRPs were preferentially bound to buccal epithelial cells. In fact, several different protein species appear to bind to cells, forming macromolecular complexes that coat the mucosa. This coating is termed a "mucosal pellicle" (distinguishing it from the enamel pellicle that coats the tooth surface, see above). In addition to the PRPs, the mucosal pellicle contains the two salivary mucin species, and may complex with other molecules such as cysteine-rich proteins and lipids [9]. It is generally considered that the mucosal pellicle provides an important protective barrier against desiccation and frictional abrasion of the oral mucosa.

Epidermal growth factor (EGF) is a small polypeptide hormone $(6000 \mathrm{Da})$ thought to function in growth, tissue repair, and the modulation of development [13]. It is also thought to protect the gastric mucosa [14]. EGF is present in saliva at levels that are adequate for regulating the growth and migration of cultured cells in vitro [15]. In humans, parotid glands are the primary source of EGF. It has been proposed that EGF may function in oral wound healing and in maintaining the oral mucosal barrier [15]. Indeed, receptors for EGF have been demonstrated to be present on human buccal mucosa [16]. Additionally, decreased salivary EGF has been correlated with certain upper gastrointestinal (GI) tract disorders. For example, patients with Barrett's columnar lined esophagus, a metaplastic condition of the esophageal lining that predisposes patients to esophageal cancer, have been shown to have lower concentrations of salivary EGF [17]. Although the full role of EGF in oral and other upper GI tract tissues is still unfolding, it appears that this growth factor may be important in the maintenance and repair of these tissues.

\section{Protection Through pH Maintenance}

An additional, less dramatic, property of saliva that must not be overlooked is its buffering capacity. Salivary bicarbonate has long been thought to protect teeth from the acidic environment promoted by cariogenic bacteria [18]. However, the ability of saliva to neutralize residual gastric acids in the esophagus has only recently been established. Even after the bulk of acid is cleared from the esophagus by peristalsis, $\mathrm{pH}$ does not begin to rise until after the first swallow of saliva [19]. In addition to inorganic bicarbonate, it is likely that the histidine-rich 
salivary peptides (histatins, see below) play a role in saliva's buffering capacity.

\section{Antimicrobial Action}

The "normal" flora present in the oral cavity, though pathogenic, generally poses no mortal risk. Its composition is the result of an evolutionary process that starts shortly after birth. Key elements involved in regulating the composition of the oral flora are the many antimicrobial proteins present in saliva; saliva contains well-described antibacterial, antifungal, and antiviral activities. Included are several antibacterial proteins that are common to many exocrine secretions, that is, lysozyme, salivary peroxidase, lactoferrin, and secretory $\operatorname{IgA}(\operatorname{sg} \mathrm{A})$. Lysozyme classically is considered to be a muramidase, degrading bacterial cell walls, but it has also been shown to have other mechanisms of limiting microbial growth. Salivary peroxidase catalyzes the formation of hypothiocyanate $\left(\mathrm{OSCN}^{-}\right)$from thiocyanate $\left(\mathrm{SCN}^{-}\right)$in saliva. $\mathrm{OSCN}^{-}$is reactive and can disrupt bacterial metabolism. Lactoferrin's principle mechanism of antibacterial action appears to be via chelation of iron, thus limiting the growth of iron-requiring microbes [10].

In addition to these nonimmune, exocrine, antimicrobial factors, there is considerable immunoprotection in salivary secretions. Secretory IgA is the predominant immunoglobulin in all exocrine secretions and is polymeric with multiple attachment sites. This multivalence causes inhibition of microbial attachment via agglutination of bacteria as well as viral neutralization [20]. Many of these pathogens are thought to have surface proteins recognized by sIgA. For example, an influenza virus surface protein, hemagglutinin (HA), is known to be involved in cell attachment. However, attachment of this virus can be prevented by HA-specific sIgA [20]. Saliva also possesses inhibitory activities against the human immunodeficiency virus-type 1 , however, the mechanisms of inactivation remain to be elucidated [21]. It appears that clearance of nonadherent pathogens through agglutination and swallowing is a major mode of oral defense.

Saliva also contains a family of proteins with potent antifungal activity, the histatins. These are low molecular weight proteins rich in histidine $(\sim 15 \%)$ that inhibit the growth and viability of Candida species. Candida albicans is a dimorphic fungus consisting of yeast and hyphae, which is present in low levels in the mouth and thought to be part of the normal oral flora. C. albicans has been shown to be very susceptible to the fungicidal properties of salivary histatins [22]. Candida can become prevalent in immunocompromised patients, a situation that can pose a considerable health risk. The specific role of histatins in modulating fungal populations in vivo remains unclear.
Fibronectin (FN) is a large cell-surface glycoprotein that primarly functions in mediating mesenchymal cell adhesion and structure. FN is present in human saliva [23], although it is not clear how it enters the secretion. FN has been shown to promote the adherence of certain bacteria to human buccal epithelial cells [24], while inhibiting the adherence of others [25].

\section{Digestion}

Saliva mediates several aspects of the initial phases of digestion. For example, saliva is the solvent for tastants in food. Further, it is the vehicle by which a tastant is delivered to the taste bud. As noted earlier, taste complaints are common among patients with salivary hypofunction. This may be secondary to generalized oral "soreness" or stem directly from loss of saliva's function as a solvent [26]. Saliva also is essential to food bolus formation and preparation of the bolus for swallowing. Several types of studies have examined this role, albeit indirectly. For example, in one study, individuals were asked questions relevant to their ability to perform an adequate swallow, and this information was compared with their stimulated salivary flow (i.e., akin to that formed during meals). Persons with complaints suggesting dysphagia had markedly lower salivary flow rates when compared with those who had no such complaints [27]. In another study, the duration of the oral phase of swallow was compared in individuals with salivary hypofunction and control subjects. Persons with salivary hypofunction showed a dramatically increased duration in the oral phase of swallowing, suggesting the presence of a saliva-related functional disorder [28]. A final important function of saliva is the initial "processing" of foods. In particular, saliva contains many hydrolases which begin the breakdown of the different macromolecules present in food stuffs (e.g., carbohydrates, proteins, nucleic acids, lipids). Thus, salivary secretions contain amylase, certain proteases, DNase, RNase, and lipase $[2,14]$.

\section{Causes of Salivary Hypofunction}

The most common causes of salivary hypofunction are iatrogenic. Most forms of anticancer therapy (radiation, cytotoxic chemotherapy, biological response modifiers, bone marrow transplantation) can result in decreased saliva production $[29,30]$. The most frequent cause of reduced saliva production in the general population is the use of medications [31]. Previously it had been believed that increased age was also associated with salivary hypofunction. However, there is now considerable evidence to suggest that saliva production is not influenced by chronological age. Rather, most earlier suggestions of 
Table 2. Medications causing decreased salivary flow rates [31]

\begin{tabular}{|c|c|c|c|}
\hline Drug class & $\begin{array}{l}\text { Marked } \\
\text { decrease }\end{array}$ & $\begin{array}{l}\text { Moderate } \\
\text { decrease }\end{array}$ & $\begin{array}{l}\text { Minimal/no } \\
\text { decrease }\end{array}$ \\
\hline Antidepressants & $\begin{array}{l}\text { Amitriptyline } \\
\text { Nortriptyline } \\
\text { Clomipramine } \\
\text { Imipramine } \\
\text { Desipramine } \\
\text { Maprotiline } \\
\text { Chlorpromazine } \\
\text { Triflupromazine } \\
\text { Doxepin }\end{array}$ & $\begin{array}{l}\text { Dothiepin } \\
\text { Zimelidine } \\
\text { Nominfensin } \\
\text { Mainserin } \\
\text { Lofepramine } \\
\text { Haloperidol } \\
\text { Thioridazine }\end{array}$ & $\begin{array}{l}\text { Cisflupenthixol } \\
\text { Citalpram } \\
\text { Transflupenthixol } \\
\text { Lithium }\end{array}$ \\
\hline Antianxiety & & & Lorazepam \\
\hline Antihypertensives & Clonidine & & $\begin{array}{l}\text { Propranolol } \\
\text { Metoprolol } \\
\text { Verapamil } \\
\text { Timolol maleate }\end{array}$ \\
\hline Diuretics & & & $\begin{array}{l}\text { Bendroflumethiazide } \\
\text { Amiloride } \\
\text { Hydrochlorothiazide }\end{array}$ \\
\hline $\begin{array}{l}\text { Anticholinergic/ } \\
\text { antireflux }\end{array}$ & $\begin{array}{l}\text { Atropine } \\
\text { Scopolamine } \\
\text { Propantheline }\end{array}$ & L-hyoscyamine & $\begin{array}{l}\text { Pirenzepine } \\
\text { Cimetidine } \\
\text { Rantidine } \\
\text { Bethanechol } \\
\text { Metoclopramide }\end{array}$ \\
\hline Antihistamines & Diphenhydramine & & \\
\hline
\end{tabular}

decreased saliva production by elderly persons were reflections of their increased medication use $[1,2]$. The most likely medications associated with reduced saliva production and the complaint of oral dryness include sedatives, antipsychotics, antidepressants, antihistamines, and certain diuretics (see Table 2). The most common disease associated with salivary hypofunction is Sjogren's syndrome, an autoimmune exocrinopathy that primarily affects postmenopausal women. It is believed that there may be approximately one million affected patients in the U.S. [31].

The production of saliva is critical for normal oral function and alterations in salivary secretions can affect many aspects of the alimentary process. Clinicians should be aware of this relationship when evaluating the dysphagic patient.

\section{References}

1. Baum BJ: Salivary gland fluid secretion during aging. JAGS $37: 453-458,1989$

2. Baum BJ: Saliva secretion and composition. Front Oral Physiol 6:126-134, 1987

3. Mandel ID: Sialochemistry in diseases and clinical situations affecting salivary glands. Crit Rev Clin Lab Sci 12:321-366, 1980
4. Fox PC, van der Ven PF, Sonies BC, Weiffenbach JM, Baum $\mathrm{BJ}$ : Xerostomia: evaluation of a symptom with increasing significance. JADA 110:519-525, 1985

5. Ship JA, Fox PC, Baum BJ: How much saliva is enough? 'Normal' function defined. JADA 122:63-69, 1991

6. Dawes C: Physiological factors affecting salivary flow rate, oral sugar clearance, and the sensation of dry mouth in man. $J$ Dent Res 66:648-653, 1987

7. Moreno EC, Varughese K, Hay DI: Effect of human salivary proteins on the precipitation kinetics of calcium phosphate. Calcif Tissue Int 28:7-16, 1979

8. Schlesinger DH, Hay DI: Complete covalent structure of a proline-rich phosphoprotein, PRP-2, an inhibitor of calcium phosphate crystal growth from human parotid saliva. Int $J$ Peptide Res 27:373-379, 1986

9. Levine MJ, Reddy MS, Tabak LA, Loomis RE, Bergey EJ, Jones PC, Cohen RE, Stinson MW, Al-Hashimi I: Structural aspects of salivary glycoproteins. J Dent Res 66:436-441, 1987

10. Mandel ID: The functions of saliva. $J$ Dent Res 66:623-627, 1987

11. Bradway SD, Bergey EJ, Jones PC, Levine MJ: Oral mucosal pellicle: adsorption and transpeptidation of salivary components to buccal epithelial cells. Biochem $J$ 261:887-896, 1989

12. Bradway SD, Scannapieco FA, Zawacki S, Rama Subbu N, Levine MJ: Mode of interaction of salivary proteins with mucosal epithelium. J Dent Res 69:319, 1990

13. Marti U, Burwen SJ, Jones AL: Biological effects of epidermal growth factor, with emphasis on the gastrointestinal tract and liver: an update. Hepatology 9:126-138, 1989

14. Valdez IH, Fox PC: Interactions of the salivary and gastrointes- 
tinal systems: I. The role of saliva in digestion. Dig Dis 9:125131,1991

15. Royce LS, Baum BJ: Physiologic levels of salivary epidermal growth factor stimulate migration of an oral epithelial cell line. Biochim Biophys Acta 1092:401-403, 1991

16. Wang S-L, Milles M, Wu-Wang C-Y, Liu J, Slomiany A, Slomiany BL: Identification of epidermal growth factor receptor in human buccal mucosa. Arch Oral Biol 35:823-828, 1990

17. Gray MR, Donnelly RJ, Kingsworth AN: Role of salivary epidermal growth factor in the pathogenesis of Barrett's columnar lined oesophagus. Br J Surg 78:1461-1466, 1991

18. Mandel ID: Relation of saliva and plaque to dental caries. J Dent Res 53:246-266, 1974

19. Helm JF: Role of saliva in esophageal function and discase. Dysphagia 4:76-84, 1989

20. McGee JR, Mestecky J, Dertzbaugh MT, Eldridge JH, Hirasawa M, Kiyono H: The mucosal immune system: from fundamental concepts to vaccine development. Vaccine 10:75-88, 1992

21. Yeh C-K, Handelman B, Fox PC, Baum BJ: Further studies of salivary inhibition of HIV-1 infectivity. $J$ AIDS 5:898-903, 1992

22. Xu T, Levitz SM, Diamond RD, Oppenheim FG: Anticandidal activity of major human salivary histatins. Infect Immun 59:2549-2554, 1991

23. Kanehisa J, Doi S, Yamanaka T, Takeuchi H: Salivary fibronec- tin in man: an immunoblotting, radioimmunoassay and immunohistochemical study. Arch Oral Biol 36:265-272, 1991

24. Simpson WA, Beachey EH: Adherence of group A streptococci to fibronectin on oral epithelial cells. Infect Immun 39:275-279, 1983

25. Simpson WA, Hasty DL, Beachey EH: Binding of fibronectin to human buccal epithelial cells inhibits the binding of type 1 fimbriated Escherichia coli. Infect Immun 48:318-323, 1985

26. Weiffenbach JM, Fox PC, Baum BJ: Taste and salivary function. Proc Natl Acad Sci USA 83:6103-6106, 1986

27. Fox PC, Busch KA, Baum BJ: Subjective reports of xerostomia and objective measures of salivary gland performance. JADA 115:581-584, 1987

28. Hughes CV, Baum BJ, Fox PC, Marmary Y, Yeh C-K, Sonies BC: Oral-pharyngeal dysphagia: a common sequela of salivary gland dysfunction. Dysphagia 1:173-177, 1987

29. Main BE, Calman KC, Ferguson MM, Kaye SB, MacFarlane TW, Mairs RJ, Samaranayake LP, Willox J, Welsh J: The effect of cytotoxic therapy on saliva and oral flora. Oral Surg 58:545548,1984

30. Valdez IH, Atkinson JC, Ship JA, Fox PC: Major salivary gland function in patients with radiation-induced xerostomia: flow rates and sialochemistry. Int J Radiat Oncol Biol Phys 25:41-47, 1992

31. Atkinson JC, Fox PC: Salivary gland dysfunction. Clin Geriatr Med 8:499-511, 1992 